upon-Tyne) who has taken the opportunity of incorporating in the present issue the deductions drawn from the work done under the Ministry's 'Grassland Campaign', and also to include a section on the comparatively new system of rotational or 'managed' grazing. The sections on the renovation of wornout grassland and seed-sowing remain substantially as written by Prof. R. G. Stapledon, of the Plant Breeding Station, Aberystwyth.

\section{Medical Research in South Africa}

Trwe annual report by the director, Sir Spencer Lister, of the South African Institute for Medical Research, Johannesburg, gives an account of the routine and research work of the Institute for the year 1933. Concentrated anti-plague serum, prepared in the Serum Department, has been tested experimentally, and has been found to have four times the protective and curative power of the unconcentrated serum, concentration being in the same ratio. Considerable difficulty has been experienced in maintaining the virulence of the plague bacillus in culture, and this difficulty has not yet been overcome. The study of pneumonia as it occurs among native miners of the Witwatersrand goldfields was continued, and the work confirms previous findings that the disease is not a pure pneumococcus pneumonia of the earlier days of the Rand, but that other organisms are associated with, or replace, the pneumococcus, namely, the streptococeus, staphylococcus and influenza bacillus. During the year, a case of human rabies due to a cat bite was observed; the incidence of human rabies infection is on the increase in South Africa, being conveyed by the cat, the tame meercat, and occasionally the dog. The observations upon dust estimation and control in the mines have been extended, and research upon several other subjects has been continued.

\section{Astronomical Phenomena in March}

Mercury is now a morning object, and attains its greatest elongation of $28^{\circ} \mathrm{W}$. on March 15. Venus, on the other hand, is moving round to its greatest eastern elongation $\left(45^{\circ} \mathrm{E}\right.$. on June 30$)$ and has already become a conspicuous object in the evening sky just after sunset. Mars is well placed for observation, being very nearly in opposition. Jupiter is a morning object, and Saturn is very near the sun. An interesting conjunction of Venus and Uranus will occur on March 22 at 7 hours, when the planets will only be separated by $0 \cdot 4^{\circ}$. This conjunction will, of course, be invisible in England, but the two planets should be seen close together, in a small telescope, on the evening of March 21 or of March 22. Neptune is well placed for telescopic observation, being in opposition to the sun on March 4.

\section{Announcements}

Prof. W. J. DE HaAs, University of Leyden, informs us by cable that on February 15 he succeeded in reaching a temperature only five thousandths $(0.005)$ of a degree above absolute zero. Particulars of this remarkable achievement will be awaited with great interest.
AT the annual meeting of the Royal Society for the Protection of Birds to be held at the Westminster Palace Rooms, 44 Victoria Street, S.W.1, on Friday, March 1, Her Grace the Duchess of Portland, president of the Society, in the chair, a motion will be submitted "That the Governments of all maritime nations be urged to give the strongest possible support to the League of Nations in their endeavours to secure the universal adoption of effective measures for preventing the pollution of the seas by oil".

IT is proposed to hold an exhibition of English periodicals and reviews in the library of the University of Coimbra, Portugal, early this year. It is hoped later to transfer the exhibition to Lisbon, Oporto and Braga. It appears that English is the second foreign language in Portugal, and a large proportion of its inhabitants have a working knowledge of the language ; but there is a general ignorance of what periodicals and reviews are published in English. It is hoped that the exhibition will remedy this state of affairs. Further information can be obtained from the Director, Biblioteca da Universidade, Coimbra, Portugal.

Referring to Mr. C. R. Cosens's letter in Nature of January 12 (p. 71) on "Designation of Logarithms to Base e", Dr. J. Satterly, of the University of Toronto, writes: "Long ago I decided that logh was too long and $\log _{10}$ and $\log _{e}$ awkward and have recently designated for blackboard work common logarithms and natural logarithms as 'ln' and 'lc', pronounced something like 'Ellen' and 'Elsie' respectively."

A BOoKLET dealing with the chloramine group of antiseptics has been issued by Boots Pure Drug Co., Ltd., Station Street, Nottingham, from whom it may be obtained free of charge. Attention is directed to the use of 'chloramine- $T$ ' and 'dichloramine- $T$ ' in the treatment of infected wounds, and to 'halazone', a most satisfactory chlorine compound for the sterilisation of drinking water.

Applicatrons are invited for the following appointments, on or before the dates mentioned :-A computer (class II) to the Ordnance Committee, Royal Arsenal, Woolwich, S.E.18 - The Secretary (Feb. 25). A lecturer in electrical engineering at Chesterfield Technical College-The Director of Education, County Education Office, St. Mary's Gate, Derby (Feb. 25). A University lecturer and a part-time University lecturer in the Faculty of Mathematics, University of Cambridge-The Secretary to the Faculty Board of Mathematics, St. John's College, Cambridge (March 2). Junior scientific officers in the Aerodynamics and Radio Departments of the National Physical Laboratory, Teddington-The Director (March 4). A resident lecturer (chemistry or physics) at Girton College, Cambridge (March 6). An assistant lecturer in zoology in the University of Bristol-The Secretary (March 11). A Henry George Plimmer fellowship in pathology at the Imperial College of Science and Technology, Prince Consort Road, London, S.W.7-The Rector (June 17). 